\title{
Reconciling Complexities of Time in Criminal Justice and Transitional Justice
}

\author{
Maja Davidović | ORCID: oooo-0oo3-3135-1340 \\ School of Government and International Affairs (SGIA), Durham University, \\ Elvet Hill Rd, DH1 3TU Durham, UK \\ maja.davidovic@durham.ac.uk
}

\begin{abstract}
This article analyses complexities of time in transitional justice (TJ) and categorises the temporal dichotomies of $\mathrm{TJ}$ processes as timeboundness/timelessness and linearity/circularity, challenging the dominant linear conception of time in the field. Criminal justice, as the most dominant TJ pillar, is seen as timebound, battling with the passage of time to avoid justice being denied or delayed. By its procedural nature, criminal justice is less capable of addressing any circularity or repetition of violence but rather treats acts of violence as ruptures in linear time. Field research in Bosnia and Herzegovina shows that the less conventional TJ processes of education and memorialisation are often given the normative content of timelessness and utilised for their capacity to capture some of the repetition of harm. In addition to establishing these distinct temporal regimes and noting any conflicts between them, the article seeks to reconcile them by repositioning criminal justice within $\mathrm{TJ}$ as a factual and legitimating foundation for education and memorialisation.
\end{abstract}

\section{Keywords}

criminal justice - education - memorialisation - temporality-Bosnia and Herzegovina

The common conceptualisation of 'transition' in transitional justice (TJ) suggests linearity of time across three definite points: the past, the present, and the future. This linear time has been temporarily ruptured by a 'transitional' 
period from the past to the future. ${ }^{1}$ Paradigmatic transitional justice, ${ }^{2}$ which employs such linearity, concerns radical shifts from old, violent regimes to new, transformed, and peaceful ones. The claimed backward- and forward-looking orientations of $\mathrm{TJ}$, whereby $\mathrm{TJ}$ seeks to both repair the past and ensure future violations are prevented are prime examples of this interest. ${ }^{3}$ The 'two-way' gaze of $\mathrm{TJ}^{4}$ theoretically underpins much of $\mathrm{TJ}$ work that frequently assumes that 'dealing' with the past will serve as a clarification of the present and a guide to the future. ${ }^{5}$

A limited collection of critical voices in TJ scholarship challenges this dominant linear narrative by pointing to expanded and multiple temporalities in transition. ${ }^{6}$ Hansen, for example, challenges the conceptualisation of transition as a limited and exceptional 'window of opportunity' by conceiving transitional justice as inclusive of times pre- and post-transitions. ${ }^{7}$ In a study on Mozambique, Igreja notes the existence of multiple temporalities that constitute indigenous understandings and practices of justice and are furthermore contested over time. ${ }^{8}$ In her analysis of temporalities of victimhood in South Africa, MuellerHirth similarly argues time and victimhood are constructed as continuous and not temporary or linear, with victims/survivors being unable or unwilling to always clearly differentiate between violent past and non-violent present, or between past and present violence. ${ }^{9}$ Mueller-Hirth notes a disparity between the

1 Z. Miller, '(Re)Distributing Transition', 7(2) Int.J. Transit. Justice (2013) 370-380.

2 I employ Dustin Sharp's term 'paradigmatic transitional justice' to describe the dominant stream of $\mathrm{TJ}$ that has prioritised civil and political rights and legal responses to justice. As Sharp argues, such priorities became "the normalized 'default" for scholars and practitioners alike. D.N. Sharp, 'What Would Satisfy Us? Taking Stock of Critical Approaches to Transitional Justice', 13(3) Int.J. Transit. Justice (2019) 570-589, p. 571.

3 R. Teitel, Transitional Justice (Oxford University Press, Oxford, 200o).

4 L. Davies, 'Justice-sensitive Education: The Implications of Transitional Justice Mechanisms for Teaching and Learning', 53(3) Comp. Educ. (2017) 333-35o, p. 333.

5 T.D. Peters, R. de Silva-Wijeyeratne and J. Flood, 'Disruption, Temporality, Law: The Future of Law and Society Scholarship?', 26(4) Griffith Law Rev. (2017) 459-468, pp. 459-46o.

6 For a comprehensive collection of work on multiple temporalities, see N. Mueller-Hirth and S. Rios Oyola (eds.), Time and Temporality in Transitional and Post-Conflict Societies (Routledge, Abingdon, 2018).

7 T. Obel Hansen, 'The Time and Space of Transitional Justice', in C. Lawther, L. Moffett and D. Jacobs (eds.) Research Handbook on Transitional Justice (Edward Elgar, Cheltenham, 2017), pp. 34-51.

8 V. Igreja, 'Multiple Temporalities in Indigenous Justice and Healing Practices in Mozambique', 6(3) Int.J. Transit. Justice (2012) 404-422.

9 N.Mueller-Hirth, 'Temporalities of Victimhood: Time in the Study of Postconflict Societies', 32(1) Sociol. Forum (2017) 186-206, pp. 188-189. 
fast-paced demands of national reconciliation and victims/survivors' individual 'pace of healing,' further conceptualising this as 'temporal conflicts'.10

This article builds on these establishments of multiple temporalities and temporal conflicts in transitional justice by examining temporal dichotomies of time-boundness/timelessness and linearity/circularity in Bosnia and Herzegovina (BiH). These conflicts arise, as Mueller-Hirth asserts, from 'differences in experiences, constructions, and uses of time,' some of which emerge as dominant and subsequently marginalise certain groups and their temporal lived experiences. ${ }^{11}$ The novelty this article introduces for the scholarship on temporality and $\mathrm{TJ}$ is its analytical focus on several $\mathrm{TJ}$ mechanisms and processes thereby seeking to theorise temporal dichotomies within the infrastructure of transitional justice. The article analyses three pillars of transitional justice, namely, criminal justice, memorialisation, and education. Paradigmatic TJ's preoccupation with criminal justice is the most representative manifestation of the dominant, linear, backward- and forward-looking conception of temporality. ${ }^{12}$ The centrality of the criminal justice pillar is reflected in both theory and practice. To name a couple of examples, the Nuremberg trials are a foundational moment for both international criminal law and transitional justice, while, according to Teitel, the most recognised symbol of the steady-state of $\mathrm{TJ}$ is the operationalisation of the International Criminal Court. ${ }^{13}$ In this article, I argue that the key temporal characteristics of criminal justice are time-boundness, as it embodies finite duration to avoid justice being delayed or denied, and linearity, seeing how criminal justice treats violence as singular episodes of rupture, sudden breaks in linear time with clear lines between start and end.

It is further contended that these two traits, characteristic of the legal ways of thinking, have mistakenly been promoted as characteristics of $\mathrm{TJ}$ in general, based on the influence of criminal justice as a key pillar of $\mathrm{TJ}$. Time has no objective temporal content but is instead given meaning subjectively. As such, arguing that temporality of the totality of transitional justice is objectively linear and timebound fails to fully capture experiences of time and violence in transitional societies. This article subsequently maintains that the processes of education and memorialisation, less commonly researched and theorised in TJ, are perceived as having temporal attributes of timelessness and circularity that oppose and seemingly conflict the temporal regimes of criminal

10 Ibid.

$11 \quad$ Ibid., p. 188.

12 Miller, supra note 2.

13 R. Teitel, ‘Transitional Justice Genealogy', 16 Harvard Human Rights J. (2003) 69-94, p. 9 o. 
justice. The normative temporal content attached to processes of education and memorialisation, unlike criminal justice, portrays attempts to show violence as circular and repetitive, harm as continuous, and alternative forms of justice as ongoing. Moreover, these processes are constructed as timeless for their capacity to transcend both the present moment and the passage of time, lasting beyond the lifetimes of interlocutors.

This article's contributions lie in its assessment of temporal dualisms between a core, field-defining mechanism and processes that seek to accommodate some of the temporal omissions of the paradigmatic, project-prone transitional justice. I therein further complicate the studies of temporality in TJ by presenting not one but two seemingly irreconcilable dualisms of linearity and circularity and time-boundness and timelessness. Although these dualisms are not new in the philosophy of time ${ }^{14}$ or social sciences and humanities, ${ }^{15}$ they are less discussed jointly in TJ. An analysis of these temporal dichotomies together allows this article to investigate multiple temporalities as contingent on one's relation towards the past as well as the future and understandings of time in relation to violence and justice. Furthermore, it helps identify certain 'grey areas' among and across temporal regimes, showing how temporal limitations of criminal justice, education, and memorialisation, respectively, can be ameliorated through temporal regimes' interactions in practice. Out of this analysis emerges a proposition about how these temporal conflicts can be reconciled in practice, as the article positions criminal justice as a factual and legitimating foundation for education and memorialisation. The proposed accommodation of multiple temporalities is made possible through the complication of temporal regimes in transitional justice. The resulting theoretical framework, built on extensive empirical work, may be useful for future developments of international criminal justice that aspire to be harmonious and 'in time' with local practices. The findings also bear relevance for TJ practice aspiring to promote holistic approaches. This holism requires sequencing of TJ processes as well as continuously negotiating their interconnectedness over the longue durée of transitional justice, a long-time span spreading beyond the short-term mandates of TJ mechanisms. Such longue durée, inclusive of

14 As Barbara Adam explains, Plato himself constructed a temporal duality of phenomena and noumena. While phenomena are time-constrained, visible, tangible, and with a prospect of an eventual end, noumena are timeless. Noumena, the ideas about the phenomena, their very essence and form were seen as atemporal by Plato. B. Adam, Time (Polity, Cambridge, 2004), pp. 26-27.

15 For example, in political theory, see discussion about J.G.A. Pocock's work, W.S. Corlett Jr., 'Pocock, Foucault, Forces of Reassurance', 17(1) Polit. Theor. (1989) 77-10o; in art, see J.P. Hodin, 'The Timeless and the Timebound in Art', 16(4) J. Aesthet. Art Crit. (1958) 497-502. 
seemingly timeless processes of memorialisation and education will also transcend and bridge TJ's episodes of 'ruptures', sudden breaks in linear time during which prosecutable violent acts occurred. ${ }^{16}$

These promises warrant a brief note on methodology. Both the establishing of temporal dualisms and their reconciliation are informed by field research in Bosnia and Herzegovina, a country that 'exemplifies contemporary transitional justice' with its multiple contemporary practices, many of which have already completed their mandates. ${ }^{17}$ With respect to criminal justice, this article focuses on criminal trials as 'the icon of the rule of law'. 18 The work of the International Criminal Tribunal for the former Yugoslavia (ICTY) in this country has been complemented by domestic courts, most notably the Court of $\mathrm{BiH}$ which has primary jurisdiction regarding war crimes prosecutions and runs a special War Crimes Section. ${ }^{19}$ While the Court of BiH hears top priority war crimes cases that are not taken up by or were redirected from the ICTY, a small number of less complex cases are heard before canton and municipal courts, most of them in cities of Banja Luka, Brčko, and Bihać. ${ }^{20}$ Education for the purposes of this article operates of formal, non-formal and informal lev$\mathrm{els}^{21}$ and concerns education about the conflict or aspects of it, through history classes or other formats such as seminars and summer schools. The discussion on memorialisation, due to the scope and (pandemic) time of this research, has prioritised physical aspects of memorialisation such as monuments and memorial sites, most of which had been documented by the Center for Non-Violent Action (CNA), an NGo based in Sarajevo and Belgrade. ${ }^{22}$ The dichotomies in tension make a claim that the temporal regimes, and not

16 O. Harris, 'Braudel: Historical Time and the Horror of Discontinuity', 57 Hist. Workshop J. (2004) 161-174, pp. 161-162; A. Castillejo-Cuéllar, 'Historical Injuries, Temporality and the Law: Articulations of a Violent Past in Two Transitional Scenarios', 25(1) Law Crit. (2015) $47-66$.

17 K. Campbell, 'Reassembling International Justice: The Making of "the Social" in International Criminal Law and Transitional Justice', 8(1) Int. J. Transit. Justice (2014) 53-74, p. 66.

18 S.S. Silbey, 'After Legal Consciousness', 1 Annu. Rev. Law Soc. Sci. (2005) 323-368, p.331.

19 Law on State Court of Bosnia and Herzegovina (Official Gazette BiH No. 49/o9, amend. 74/o9, 97/o9). osCE, Mapa procesurianih ratnih zločina u BiH, available online at https://maparz. pravosudje.ba/bhs (accessed 8 July 2020).

21 These would include, inter alia, outreach activities that spread awareness about $\mathrm{TJ}$, informal educational spaces such as museums and memorials, and formal education institutions such as schools. See M.J. Bellino, Julia Paulson and Elizabeth Anderson Worden, 'Working through Difficult Pasts: Toward Thick Democracy and Transitional Justice in Education', 53(3) Comp. Educ. (2017) 313-332, p. 317.

22 Centar za nenasilnu akciju, RAT SJEĆANJA. Istraživanje o Mjestima Stradanja i Sjećanja Na Rat u BiH (Centar za nenasilnu akciju, Sarajevo and Belgrade, 2018). 
necessarily the substance of these three processes are in clash. Finally, my field research, from which the following theorisation stems, involved semi-structured interviews with 48 local and international TJ actors in BiH. These included 15 judges, prosecutors, and legal experts, while other actors are classified as civil servants, NGO representatives, international organisations (IO) representatives, curators, and academics. I also conducted in-person observations of three war crimes trials before the Court of BiH between November 2019 and February 2020.

The article proceeds as follows. Section 2 offers a review of the theoretical underpinnings of time in transitional justice. Section 3 introduces numerous empirical examples to support the claim that criminal justice is time-bound and that it treats violent acts as ruptures in linear time, failing to fully capture lived experiences of time, justice, and violence. I further nuance these temporal limitations and explain how some of the blurring of temporal regimes occurs. The subsequent section explores memorialisation and education, making an argument for their timelessness and capacity to speak for circularity and repetition of violence. In Section 5 , it is suggested that reconciliation of the two temporal regimes occurs when education and memorialisation become fora for more permanent visibility of both recognition and accountability that stem from criminal justice.

On Time and Transitional Justice

The dominant narrative of linearity of time found in $\mathrm{TJ}$ is characteristic of the measuring of time in Western societies, linked to the birth and development of technology and the mechanical clock. ${ }^{23}$ With the wide acceptance of the clock, time became perceived as quantifiable, measurable, expressed in simple numbers, 'unaffected by the transformation it describes. ${ }^{24}$ Most prominently, Isaac Newton thought of this measurable time as objective, absolute, unchangeable, flowing linearly without interruptions. ${ }^{25}$ In this linear perception of time, the future becomes something that could be predicted and expected based on a steady repetition of the same events at particular times of the day, week, or year. ${ }^{26}$

23 Adam supra note 15. See also B. Adam, Time and social theory (Polity, Cambridge, 1994).

24 Ibid., p. 3 o.

25 Ibid., pp. 29-31.

26 Ibid., p. 43. 
The dual orientation of transitional justice as both backward- and forward-looking manifests linear, objective and measurable time. Teitel famously conceives of law in TJ as 'caught between the past and the future, between backward-looking and forward-looking, between retrospective and prospective. ${ }^{27}$ One of the main conundrums Teitel deals with is the paradox of law in transition, whereby law not only provides order and stability as per ordinary times but also enables transformation, an improved future. Legal transitional responses, therefore, bridge the past and the future. Almost by default, the scholarship that followed Teitel's work saw TJ as both past and future-oriented. Many individual TJ mechanisms are said to be able to be both backward- and forward-looking. ${ }^{28}$ Two central premises for the field of TJ today stem from this theorisation. First, legal tools for dealing with the past, such as criminal trials, as positioned on the linear flow of time as being in between the past and the future; as being capable to repair the past and (and in order to) deter recurrence of similarly grave violations in the future. Second, transitional justice is claimed to be well-equipped to provide a better, more peaceful, and democratic future due to its 'dealing' with the past in a short-term, time-framed way while the 'transition' lasts. This particular understanding of time in TJ sits well with the bulk of the early TJ theory and practice that can be characterised as policy-oriented, ${ }^{29}$ describing and prescribing solutions to observed problems. ${ }^{30}$ It is this kind of research that argued, for instance, that criminal tribunals boost peacebuilding processes, ${ }^{31}$ or that truth commissions improve levels of reconciliation, ${ }^{32}$ and that further buttressed the core argument that addressing the past through these institutions, linearly and within a specific time limit, links to an improved future.

Critical and interdisciplinary scholarship challenges this dominant narrative by providing more insights into the neglected temporal complexities. For many victims/survivors and their families, time might not flow linearly, even

27 Teitel supra note 4, p. 6.

28 On truth commissions, see M. Urban Walker, 'Nunca Más', in L. May and E. Edenberg (eds.), Jus Post Bellum and Transitional Justice (Cambridge University Press, Cambridge, 2013), pp. 262-284. On reparations, see R. Uprimny Yepes, 'Transformative Reparations of Massive Gross Human Rights Violations: Between Corrective and Distributive Justice', 27(4) Neth. Q. Human Rights (2009) 625-647.

29 Sharp, supra note 3.

$30 \quad$ J.R. Rowen. "'We Don't Believe in Transitional Justice." Peace and the Politics of Legal Ideas in Colombia', 42(3) Law Soc. Inquiry (2017) 622-647.

$31 \quad$ P. Akhavan, 'Beyond Impunity: Can International Criminal Justice Prevent Future Atrocities', 95(1) Am. J. Int. Law (2001) 7-31.

32 J.L. Gibson, 'Overcoming Apartheid: Can Truth Reconcile a Divided Nation?', 6o3(1) Ann. Am. Acad. Polit. Soc. Sci. (2006) 82-110. 
after a trial is completed. Katz and Shalev Greene, who interviewed families of the missing in Israel, find that due to the uncertainty about the fate of the missing, linear conceptions of time are disrupted. ${ }^{33}$ For some of their interviewees, time becomes perpetual, as the missing relative was neither alive nor dead and the crime of disappearance was ongoing. Instead, 'missingness' appears as a stable category in which linear time no longer exists neither for the missing nor for their families. ${ }^{34}$ Similarly, Bueno-Hansen has discussed the perceptions of time by the relatives of the missing as 'suspended' ${ }^{35}$ In her study of genocide survivors in Rwanda and memorialisation practices of 'care-taking', Viebach argues that linearity of time is 'broken' and discontinuous after mass violence where the past, present, and future seem unconnected. ${ }^{36}$

These distinct streams of temporality as, on the one hand, linear and singular, and on the other hand, circular and multiple, can be well-supported by social theory, particularly the work of George Herbert Mead. Mead held that the past is not fixed but instead changeable, continuously recreated into a different past in the present. ${ }^{37}$ The relationship between the past and the present, therefore, implies that the past does not have an isolated standing without its relation to the present. Similarly, the future, too, is open in the present, able to be adjusted and selected. Hence, for Mead, reality exists in the present and present only, and this present has not 'emerged' from the past but has always integrated values and institutions of the past. ${ }^{38}$ Both the past and the future exist only as long as they are referential to the present. This present, in turn, is always new, always transforming, an unending process.

Here is where time becomes conceived as relative, at times circular, and where certain present events can become perceived as repetitions or continuations of the past. Time begins to be seen as having normative content that is subjectively assigned by victims/survivors, their families and bystanders, as per the literature above. This normative content can be in direct clash with the conventional linear perceptions of time in $\mathrm{TJ}$ that claim to be objective and independent from those experiencing time in the present. In order to be

33 O. Katz and K. Shalev Greene, 'Constructing Time in Uncertainty: Temporal Regimes among Missing Persons' Families', 69 Curr. Sociol. (2020) https://doi.org/10.1177/oo11392120902235.

34 Ibid., p. 14.

35 P. Bueno-Hansen, Feminist and Human Rights Struggles in Peru: Decolonizing Transitional Justice (University of Illinois Press, Champaign, IL, 2015) p. 153.

36 J. Viebach, 'Of other times: Temporality, memory and trauma in post-genocide Rwanda', 25(3) Int. Rev. Victimol. (2019) 277-301, p. 287.

37 G.H. Mead, The Philosophy of the Present (Open Court Publishing, Chicago, IL, 1959) Chapter I.

$38 \quad$ Ibid. 
neutral, this kind of linear time is detached from 'experience and memory,'39 and, just as technocratic approaches to $\mathrm{TJ}$, can be standardised and exported across contexts. Upon the completion of a predetermined set of technocratic measures in the present, such as criminal trials or institutional reform, the predicted peaceful, socially engineered future begins. Yet, as per Mead's theorisation, it is the present that holds a special status as the place from which the classification is made. This present interacts with personal accounts of both past and future and, in transitional societies, is dependent on both the character of the ongoing transition and the existing elements of transitional justice as contexts in which experiences of time are lived..$^{40}$ There are two elements to this theorisation. First, perceptions of linearity and circularity of time typically relate to one's present relation to the past, and second, perceptions of time-boundness and timelessness of TJ process reflect their relations to the future. The time-boundness/timelessness dualism mirrors individuals' perceptions of TJ processes as lasting in our immediate perceivable future-one that can start tomorrow, next week, or next year-or as enduring in the future not perceivable by us in our lifetimes - a future that cannot begin. That said, timelessness does not mean that education and memorialisation are out of time, separate from the continuous process of the construction of time, but that they are perceived as out of our lifetime. These are not separated as strictly matters of the past and strictly matters of the future but instead negotiated in the present. The past continues to vary as the future present varies, ${ }^{41}$ and 'dealing' with the past remains an ongoing process. The following two sections build on these arguments with empirical insights on the temporalities attached to criminal justice, education, and memorialisation.

Criminal justice is timebound, not because the will to prosecute perpetrators of international crimes diminishes over time ${ }^{42}$ —although it might—but because the legal, procedural, and biological limitations imposed on criminal justice prevent it from continuing in its established form after a certain time has passed. That criminal justice processes must end in transitional contexts is

39 Adam supra note 15, p. 114.

40 Katz and Shalev Greene, for instance, study 'temporal regimes' which include both a subjective and relational sense of time, stemming from cultural and social negotiations of temporalities. Katz and Shalev, supra note 33.

41 Mead, supra note 38.

42 Teitel, supra note 4. 
not too surprising, for they are designed as time-limited to avoid justice being delayed and/or denied. The argument commonly put forward is that the completion of trials will serve as an occasion for a claimed closure, proclaiming justice as 'done' and a better, just future can begin. ${ }^{43}$ Hence, criminal justice is rightly time-constrained.

Empirical examples from Bosnia and Herzegovina reveal a consensus about the necessity and reality of criminal justice's time-boundness while also confirming several obstacles to speediness. In the 25 years since the Dayton Peace Agreement was signed, criminal justice has by far been the most dominant $\mathrm{TJ}$ pillar in $\mathrm{BiH}$. According to the War Crimes Map, created by the OSCE, at least 516 cases have been completed before domestic courts in BiH as of February $2021 .{ }^{44}$ The majority of them, and the most complex cases among them, have been processed by the Court of $\mathrm{BiH}^{4}{ }^{45}$ Trials that involve adjudicating on crimes such as genocide are known to be very long for a variety of reasons, some of which are linked to legal procedures. To find a defendant criminally responsible for a complex crime such as genocide, the court must consider a set of typically entangled circumstances, spending days in court hearing evidence regarding what happened during the alleged act as well as what led to it. For these matters among others, the ICTY took 23 years to officially close, although some of its 'essential functions' including retrials and appeals, and maintaining legacy ${ }^{46}$ are kept in the International Residual Mechanism for Criminal Tribunal (IRMCT) ${ }^{47}$ As of early 2021, there were still four open cases before the IRMCT, including the case of Ratko Mladić, who was indicted in 1995 (still on appeal at the time of writing), and the retrials of Simatović and Stanišić. ${ }^{48}$ Domestic trials in $\mathrm{BiH}$, too, are still ongoing, although their expiration date is

43 Booth, for instance, critiques this. W.J. Booth, 'The Unforgotten: Memories of Justice', 95(4) Am. Polit. Sci. Ass. (2001) 777-791.

44 OSCE, supra note 21. It should, however, be noted that the National strategy for war crimes adopted in 2008 estimated at least 10 ooo suspects, only a tenth of whom were under active investigation at the time. See Ministarstvo pravde Bosne i Hercegovine, Državna strategija za rad na predmetima ratnih zločina, available online at http://www.mpr.gov.ba/ web_dokumenti/Drzavna\%2ostrategije\%2oza\%2orad\%2ona\%2opredmetima\%2oRZ.pdf (accessed 8 July 2020).

45 Between 2004 and 2019, the Court ruled on 242 cases, finding 261 people guilty for genocide, crimes against humanity and/or war crimes. Sud Bosne i Hercegovina, Statistika o presudama Suda BiH za period 2004.-2019. godina, available online at http://www.sudbih.gov. $\mathrm{ba} /$ stranica/102/pregled (accessed 8 July 2020).

46 International Residual Mechanism for Criminal Tribunals, About, available online at https:// www.irmct.org/en/about (accessed 8 July 2020).

47 United Nations Security Council, Resolution 1966 (S/REs/1966).

48 International Criminal Tribunal for the former Yugoslavia, Cases before IRMCT, https://www. icty.org/en/cases-before-irmct accessed 23 February 2021. 
often discussed. Due to a large number of unsolved war crimes cases in 2007, a working group was established to draft a national strategy for prosecuting war crimes cases. ${ }^{49}$ The strategy, launched in 2008 , envisaged that the complex and priority cases would be processed in seven years, and the rest, usually, but not always, left to lower-level municipal and canton courts, within 15 years. Since the most complex cases were nowhere near completion seven years later, a revised strategy was drafted, obliging state courts to process all war crimes by $2023 .^{50}$

Domestic courts continue business as usual but face some pressures to 'finish' their mandates. Local judges and prosecutors share this sentiment, as I observed in the Court of $\mathrm{BiH}$. As I sat in the courtroom in the Prosecutor v. Esad Ramić et al. case, I heard the lead judge urge the prosecutor to 'hurry' with more material evidence. It is a complex case with 13 defendants accused of crimes against humanity, ongoing since 2018. On the day I visited, the prosecution's witness gave a lengthy testimony about the events before and after the massacre. Yet, the judge reminded the prosecutor that already 50 witnesses were heard talking about these same circumstances in which the massacre was committed, such as the demographics and the ethnic composition in the village. Of course, there are no procedural rules about how many witnesses would suffice to establish such circumstances. An interviewed prosecutor suggested that regardless of how slow or fast procedures are, the victim will always think that the process can be done better and faster. ${ }^{51}$ This suggests that the pace of criminal justice in the context of international crimes and the expectations of the victims as to how speedy the procedures should be are inherently in tension. While cognisant of the successes of criminal justice in the country, the prosecutor showed understanding for these perceptions. 'Justice is slow', he told me.

Even though criminal trials in $\mathrm{BiH}$ will certainly continue for several years into the future out of fears of denied justice and the triumph of impunity, often, their time has already passed. In our interactions, $\mathrm{BiH}$ prosecutors and judges working on war crimes cases often voiced concerns about how time-boundness affects the present-day work of criminal justice institutions. One judge told me he was unsure how much courts can contribute to transition with their judgments,

49 Ministarstvo pravde BiH, supra note 45.

$5^{\circ}$ Ministarstvo pravde Bosne i Hercegovine, Revidirana državna strategija za rad na predmetima ratnih zločina, available online at http://www.mpr.gov.ba/web_dokumenti/ default.aspx?id=108og\&langTag=bs-BA (accessed 22 February 2021).

51 Interview with a prosecutor, 29 November 2019, the Prosecutor's Office of East Sarajevo. 
especially as time goes by. ${ }^{52}$ Over time, he asserted, victims and witnesses are less motivated to participate. Nowadays, the judge explained, witnesses 'beg the court not to call them in again, [since] they do not want to remember anymore'. Some victims think they have nothing to gain after so much time has passed, a local prosecutor added. The pressures to 'complete' criminal justice in due course therefore occasionally go directly against certain victims' wishes. 'They do not want to disturb their peace that was so hard to obtain ... especially if the case concerns sexual violence.'53 Another prosecutor from Banja Luka described a similar observation:

There are people who left Republika Srpska ${ }^{54}$ [during the war], returned 2001-2003, and now live in these communities. They started their lives anew, they have jobs, contacts in the community. ... They have a feeling that this [trial] would disturb it, that people would look at them differently [so they say], 'come on now, do not do it, it happened in the past, it is not important'. 55

Another aspect of time-boundness is the aging of the alleged perpetrators. The former President of Yugoslavia, Slobodan Milošević died in The Hague before the ICTY managed to rule on his case and many saw this as a failure to deliver justice to the numerous victims harmed by his actions. ${ }^{56}$ The risk of having the defendant die or fall seriously ill during a trial has only increased in the last few years. The interviewed prosecutors were eager to stress the aging aspect. In Brčko, for example, it is not the lack of resources they were struggling with but the passage of time. 'Time does its job', one of the prosecutors told me, 'witnesses die, victims die, defendants, too ...'57 Death is not the only biological obstacle, but so are fading memories. The Brčko prosecutors discussed their hardships in obtaining new evidence. After more than 25 years, they asserted, it is questionable if the witness will remember much. 'The witness is the worst evidence', one of the prosecutors contended. ${ }^{58}$

\footnotetext{
52 Interview with a judge, 13 November 2019, the Basic Court of the Brčko District.

53 Interview with prosecutors, 13 November 2019, the Prosecutor's Office of the Brčko District.

54 Republika Srpska, of which Banja Luka is the administrative centre, is an autonomous entity in the federative system of Bosnia and Herzegovina.

55 Interview with a prosecutor, 26 November 2019, the Prosecutor's Office in Banja Luka.

$5^{6}$ See generally J.N. Clark, Serbia in the Shadow of Milosevic: The Legacy of Conflict in the Balkans (Bloomsbury, London, 2008).

57 Interview with prosecutors, supra note 54.

$5^{8} \quad$ Ibid.
} 
Although Teitel wrote about the uncovering of new aspects of the offenses, including perpetrators' identities and factual circumstances of the act with time, ${ }^{59}$ this has not materialised in BiH. Much of the discouragement to come forward with new information about a case comes from the political climate in $\mathrm{BiH}$ and the capture of transitional justice narratives by nationalist political elites. To shed a light on a criminal act, even anonymously, can be seen as treason to one's ethnic group and result in a life in perpetual fear. ${ }^{60}$ However, the lack of new evidence is also a consequence of the passage of time. The efforts to locate and exhume the remaining 7,000 missing persons in $\mathrm{BiH}$ have been drastically impeded in the past few years. ${ }^{61}$ Overall, it is a success story with the remains of over 70 per cent of those originally declared missing in the conflict exhumated and identified. When asked why the process of identification had been slowing down, a representative of the International Commission for Missing Persons in BiH simply responded 'the passage of time'.62 She explained how before, out of ten new exhumations, they would have had only one miss, a false clue. 'Nowadays, it is reversed. You would have 6o exhumations and no single remain found. [...] Witnesses die, people move, there is no more interest', she concluded. One of the three members of the Board of Directors of the Missing Persons Institute shared these concerns:

We often deal with cases where people take us to an alleged grave location and, after twenty years, they cannot orient themselves on that field; the vegetation has changed, perhaps new trees have grown in the meantime... ${ }^{63}$

Criminal justice in transitional times, therefore, confronts a hurdle that seems impossible to pass. After a certain passage of time, it becomes increasingly more difficult to complete a criminal trial. When this much time has passed, and criminal trials are not completed and do not have the prospects of being so, more people become frustrated seeing justice as denied and judicial processes

59 Teitel, supra note 4.

6o Human Rights Watch, Still Waiting Bringing Justice for War Crimes, Crimes against Humanity, and Genocide in Bosnia and Herzegovina's Cantonal and District Courts (Human Rights Watch, New York, NY, 2008), available online at https://www.hrw.org/reports/2008/bosniao708/ bosniao708web.pdf (accessed 23 February 2021).

61 As of December 2019, the official statistics of those who remain missing was 7, 314. Interview with a representative of the Missing Persons Institute, 17 December 2019, Sarajevo.

62 Interview with a representative of the International Commission on Missing Persons, 6 December 2019, Sarajevo.

63 Interview with a representative of the Missing Persons Institute supra note 62. 
as incomplete or biased. By the nature of the transitional context in which it operates, criminal justice will leave someone excluded.

In addition to the time-boundness, criminal trials operate on the linear flow of time, examining acts of violence that, for the trial, have a definite beginning and a definite end. At the very core, the final declaration of accountability is dependent on the accused's role in the act itself, whether it is committing, ordering, aiding, abetting, or otherwise assisting the (attempted) commission, a role that is temporary. ${ }^{64}$ Such attributes cement the linearity of law and ensure its continuity based on strict procedural obedience. The core premise of criminal trials is that objective, linear time, seemingly socially shared, could be regulated by the law and legal institutions. Yet, by employing a set of seemingly objective criteria detached from personal experience, criminal justice treats a violent act as a rupture in the linear flow of time. This rupture represents a sudden and objectively defined break in linear time and, as Aksenova argues in the context of international criminal law, it symbolises 'the collapse of a shared collective identity' that the law is capable of recreating. ${ }^{65}$ Treating violence as a rupture in linear time has consequences. Giving an example of the 'battered woman syndrome' and domestic violence in ordinary, non-transitional time, Nousiainen shows that the time frame chosen by the law decides whether the previous abuse of the victim-turned-perpetrator is included in the crime or not. ${ }^{66}$ The presumption exists that the normative content of time in this time frame is objective and thus the same for the victim-turned-perpetrator, the perpetrator-turned-victim, and the law. In other words, it is presumed that the rupture took place at one particular moment and lasted for a definite period, the understandings of both of which are shared by all parties. The decisions made regarding time framing therein impact both the extent and type of the abuse that is judged. Moreover, that violence is a rupture necessitates some clear determination of good versus evil. As Simpson argues, domestic war crimes trials frequently distinguish the prosecuting state as the 'absolute good' - as opposed to the 'ultimate evil' the accused individuals represent—and relatedly exculpate

64 See Article 25 on individual criminal responsibility, the Rome Statute of the International Criminal Court, (amended on 11 June 2010 by resolution RC/Res.6).

65 M. Aksenova, 'The Role of International Criminal Tribunals in Shaping the Historical Accounts of Genocide', in U. Belavusau and A. Gliszczynska-Grabias (eds.), Law and Memory. Towards Legal Governance of History (Cambridge University Press, Cambridge, 2017), pp. 48-69, p. 53 .

66 K. Nousiainen, 'Time of Law - Time of Experience', in J. Bjarup and M. Blegvad (eds.), Time, Law and Society. Proceedings of a Nordic Symposium Held May 1994 at Sandbjerg Gods, Denmark (Franz Steiner Verlag, Stuttgart, 1995) pp. 24-38. 
those who prosecute this evil. ${ }^{67}$ The violent act in question will be treated as singular evil, extracted from its wider political and socio-economic contexts. It follows from this proposition that certain acts of violence and abuse will not be prosecuted and that the strive against impunity can at best be selective.

Nevertheless, such linear treatments of violence can also trigger dissident non-linear narratives seeking to challenge the dominant temporal regime. These acts of dissidence can happen during the trial, aspiring to undo the main story and bring in the ignored contexts and cases of other or different violence. ${ }^{68}$ An illustrative example is the trial of Klaus Barbie where the defence counsel aspired to shift the positioning of the trial as documenting the superiority of Western liberalism over Nazism into a trial of French imperialism. ${ }^{69}$ Rangelov, for example, argues that criminal trials such as Barbie's served 'as vehicles for public debate' on the accepted linear narratives and any other violent episodes the trials omit. ${ }^{70}$ By triggering public engagement in productive debates about the interpretation of the 'facts' of the past violence, these linear and time-bound trials allowed the public to notice the hidden continuities in nationalism that are implicated in past violence. Consequently, outside the courtroom, trials can allow for a disruption of the narrative of violence as 'rupture', as critical assessments shift between the past and the present and call for rethinking of future prosecutions in light of the nationalist continuities.

These unintended consequences concern contextualising the violent act in question and scrutinising the broader structures of nationalism, imperialism, and such that surround it. Some of the linearity is challenged in this way; yet, considering time-boundness of criminal justice as well as linearity reminds us that multiple cases and forms of violence will be excluded from criminal justice processes and, subsequently, public debates. The criminal trial in particular cannot reach as far as considering the possibility that a crime is already perceived as a repetition by those affected. Take, for instance, the case of a small village of Orašlje near Stolac, BiH, where German occupiers and their collaborators executed 62 civilians on the 12 July 1943 and Croatian armed forces killed 15 on the 13 July 1993 , exactly 5 o years later. ${ }^{71}$ The perpetrators might not be the

67 G.J. Simpson, 'Didactic and dissident histories in war crimes trials', 6o(3) Albany Law School Rev. (1997) 801-840, pp. 826-827.

68 For different empirical examples of this, see Ibid.

69 Ibid., p. 833 .

70 I. Rangelov, Nationalism and the Rule of Law: Lessons from the Balkans and Beyond (Cambridge University Press, Cambridge, 2013) p. 48.

71 M. Behram, 'Jedno selo, dva zločina u pet decenija', Radio Slobodna Evropa (14 July 2015), available online at https://www.slobodnaevropa.org/a/ponavljanje-zlocina/27127436.html (accessed 6 July 2020). 
same, but the victims are. Some of them survived the 1943 massacre only to be killed 50 years later. Other survivors lost their grandparents in the first massacre and parents in the second. Although no criminal proceedings were ever initiated for either massacre, if they were to begin today, they would only concern the events that took place in 1993 by way of 'discovery' of that past event as an independent episode. ${ }^{72}$ The trial therefore would not capture the lived experience of people in Orašlje who see the two massacres as interlinked, nor could it recognise individuals' intergenerational trauma which affects one's temporal experiences. ${ }^{73}$ Criminal justice is procedurally incapable of accommodating this dual victimisation and victims' perception of the latter massacre as a repetition, and perhaps even a consequence of the former, leaving distinct temporalities and people experiencing them on the margins.

In transitional contexts in particular, as my illustration from Orašlje shows, violent acts are rarely understood as ruptures whose beginning can be pinpointed on linear time that continues to flow undisturbed after the event. In terms of temporality, they are not singular short-lasting events that could be isolated and examined on their own without considering other influences. Consequently, TJ mechanism of criminal justice disregards more structural dimensions of violence that are interlinked with longue durée. ${ }^{74}$ Reframing criminal justice as timeless and non-linear would be an impossibility, notwithstanding certain 'grey areas' discussed above where criminal justice opens spaces for the involved parties and the public to express different conceptualisations of the temporality of violence and justice. ${ }^{75}$ Instead, the following section explores how processes of memorialisation and education can disrupt both time-boundness and linearity as dominant temporal regimes.

The Timelessness and Non-Linearity of Memorialisation and Education

In transitional justice, memorialisation and education are often interlinked and largely conceptualised as working with the past for the benefit of the future. Memorialisation practices are typically closely linked to the moral 'Never

72 Mead, supra note 38, p. 7 .

73 On the latter point, see Viebach, supra note 37, pp. 291-292.

74 Such violent acts, e.g., forced migration, are subsequently omitted from the official policies of reparation. Castillejo-Cuéllar, supra note 17.

75 I would like to thank Stefanie Kappler, Olga Demetrious and the two anonymous reviews for stressing this point. 
Again' promise which gives it a framework for discussing different aspects of memorialisation and their usefulness. ${ }^{76}$ The general idea, as Clark describes it, is that '[o]nly by remembering ... can we learn from the past' and not repeat it. ${ }^{77}$ For instance, museums that depict the struggle of victims and survivors of oppression or violence are often seen as educational sites where audiences can be introduced to the horrors of violence and deterred from resorting to the same forms of abuse in the future. ${ }^{78}$ However, singular and linear temporality linked to mnemonic practices has been challenged in TJ literature. As MuellerHirth and Rios Oyola assert, memories of violence can fit into linear forms, but they can also be 'embodied, ritual, non- or poly-discursive. ${ }^{79}$ Viebach, for instance, draws on field research to propose the production, reproduction, and co-existence of multiple temporalities attached to commemorative practices. ${ }^{80}$ This work shows that memory 'refuses to be confined, and defined' by linear, institutionalised $\mathrm{TJ}$ mechanisms. ${ }^{81}$

Although still under-researched in $\mathrm{TJ}$, education is positioned as a crucial factor contributing to lasting peace in an emerging body of literature. ${ }^{82}$ By way of example, Bellino, Paulson and Worden argue that education and TJ have the potential to contribute to 'thick democracy' that would result in meaningful civic participation that furthers social justice and lasting peace. ${ }^{83}$ Yet, the temporality of education in TJ has rarely been studied and the linear flow of time is presumed. Notably, Lynn Davies conceives of 'justice-sensitive education' as using the 'two-way gaze' of TJ-looking both backward and forward-to understand how it can create a better, rights-respecting future. ${ }^{84}$ As a whole, Davies argues, the dual, backward- and forward-looking orientation of $\mathrm{TJ}$ is beneficial as it teaches the importance of understanding what was undemocratic about the past, leading to more awareness of why 'a full democracy'

76 J.N. Clark, 'Reconciliation through Remembrance? War Memorials and the Victims of Vukovar', 7(1) Int. J. Transiti. Justice (2013) 116-135.

77 Ibid., p. 117.

78 N. Mookherjee, "Never Again": Aesthetics of "Genocidal" Cosmopolitanism and the Bangladesh Liberation War Museum, 17 J. Roy. Anthropol. Inst. (2011) 571-591.

79 N. Mueller-Hirth and S. Rios Oyola, 'Introduction: Temporal perspectives on transitional and post-conflict societies' in Mueller-Hirth and Rios Oyola, supra note 7, p. 9.

8o Viebach, supra note 37.

$81 \quad$ Ibid.

82 Bellino, Paulson and Anderson Worden, supra note 22.; C. Ramirez-Barat and R. Duthie, Education and Transitional Justice: Opportunities and Challenges for Peacebuilding (International Center for Transitional Justice, New York, NY, 2015); E. Cole, Teaching the Violent Past: History Education and Reconciliation (Rowman and Littlefield, Lanham, 2007).

83 Bellino, Paulson and Anderson Worden, supra note 22.

84 Davies, supra note 5, p. 333 . 
is crucial for sustainable peace. ${ }^{85}$ While Davies admits that change does not always occur linearly, she nevertheless comprises such non-linearity on the basis of potential interruptions that prevent the transformative potential of education.

A series of empirical examples from $\mathrm{BiH}$ indicate that distinct experiences of temporality in transition can be and are accommodated through memorialisation and education processes, reflecting some of the non-linearity and circularity of time and violence. Numerous monuments and memorial sites found in BiH bring the events from the past two wars together, including the one found in the village of Orašlje. To name another one among many, in the town of Višegrad, a monument was erected to commemorate all murdered and disappeared Bosniak children, women, and men. The inscription reads 'Witnesses of the Truth 1992-1995 and Witnesses of the Truth 1941-1945' ${ }^{86}$

Bringing victims of two or more wars together is not only a product of people's individual and transgenerational memory and an aspiration to enlarge one's victimhood, although this surely happens. It is also a product of the teaching of history, as well as of the stories of repetition. Like in Orašlje, where the same families fell victim to the occupiers twice in 50 years, or in the case of Hrastova glavica where perpetrators in two separate wars used the same pit to hide the bodies of the victims they had executed. ${ }^{87}$ In 1998, the remains of 126 human bodies were found inside this cave-like pit. Exhumations revealed that 124 of the victims were camp prisoners from the 199os concentration camps of Keraterm and Omarska, as suspected; yet two of them were not - they were executed in WWII. In 2012, two citizens' associations from the region placed a memorial plaque and closed the entrance to the pit with an iron bar. The inscription on the plaque suggests that this is done 'hoping that innocent people will never be thrown into this pit again'. Memorials that bring two or more conflicts together, therefore, demonstrate interpretations of violence as connected and repeated and understandings of temporal continuity of the conditions that enable violent acts across conflicts. They do not necessarily symbolise actions of looking back to ensure a peaceful future but experiences of continual struggle and continual fear of repetition of violence, towards the same group of people in similar manners. Although subject to individual engagement, they offer more insights into the existence of structural conditions in and out of which violent acts are borne, such as ethnic discrimination. Unlike criminal justice, these memorials can suggest that these structural

$85 \quad$ Ibid., p. 336.

86 Centar za nenasilnu akciju, supra note 23 .

87 Ibid. 
conditions are not removed with the completion of time-bound TJ processes such as trials.

The continuity and fear of repetition are well-dealt with topics in local TJ actors' work on education. In their view, public education in $\mathrm{BiH}$, which divides pupils on ethnic bases, is actively creating 'hateful' youth that would be 'more prepared, more extreme' than older generations should another conflict arise. ${ }^{88}$ Reforming formal education matters because, as one NGO representative told me, in the absence of unified history education for all ethnicities, since 1995, new generations have been left with family members' interpretations of what happened. ${ }^{89}$ They grow up in a 'very confusing world', suspect to new divisions along ethnic lines. Personal traumas and fears are transmitted to the new generations who, it seems like, cautiously wait for another conflict. ${ }^{90}$

To compensate for the flaws in formal education, many informal educational projects strive to enable the creation of a common peaceful narrative as their way to combat the seemingly pending 'repetition of violent history' that many observe in the region. Occasionally, informal educational activities also bring the narratives from the two wars together. Participants of the School of Different Memories, run by the Youth Initiative for Human Rights in $\mathrm{BiH}$, for example, discuss events from the last two wars and visit places such as Orašlje. The logic is the following, the School's coordinator explained:

crimes happened in the 1940s, but they were not talked about. They were pushed under the rug for the ideas of brotherhood and unity [...] Simply, they were neglected $[\ldots]$ And then it happened that you had ... a general enter a [Bosnian] town [in the 199os] saying 'this is revenge for 500 years of the Ottoman rule, revenge for this, revenge for that'. ${ }^{1}$

The NGO emphasises these repetitive and continual aspects because they believe, the coordinator told me, that if they do not educate about both sets of events now, the only logical expectation is that they will be repeated soon. ${ }^{92}$

88 Interview with an academic and former civil servant, 12 December 2019, Sarajevo. Interview with a civil servant, 10 February 2020, Sarajevo. G. Šimić, 'To Believe or Not to Believe: Current History Textbooks in Bosnia and Herzegovina', in G. Ognjenović and J. Jozelić (eds.), Nationhood and Politicization of History in School Textbooks: Identity, the Curriculum and Educational Media (Palgrave Macmillan, London, 2020), pp. 155-179.

89 Interview with an NGO representative, 6 November 2019, Sarajevo.

90 Interview with an NGO representative and TJ expert, 12 November 2019, Bijeljina.

91 Alluding to Ratko Mladić's speech upon entering Srebrenica on 11 July 2015. Interview with an NGO representative, 11 December 2019, Sarajevo.

92 Ibid. 
Generations who can remember the war will not start a new one for multiple reasons, the interviewee concluded, but the problem arises with new generations with no personal memory of wars yet very pervasive divisive narratives about them. These divisive narratives point to continuity and not interruptions in linear time as per criminal justice understanding. 'The war is not over. Not in our heads', another interviewee added..$^{93}$

In these perceptions of the relationship between the present and the future, processes of memorialisation and education come out as timeless. Particularly when the two go hand-in-hand it is the educational components of memorialisation processes that are stressed as crucial for the non-repetition of violence, long-term. A local TJ expert held that " $[\mathrm{t}]$ his is something that will outlive all of us. This type of commemoration and memorialisation is something that will outlive the present-day generations that are perhaps still witnesses of time. ${ }^{94}$ These processes are timeless because they do not conform well with the typical elements of time-boundness such as points in time and limited durations. ${ }^{95} \mathrm{~A}$ memorial might have a start of its physical manifestation, but it does not necessarily have the beginning of what it represents. Furthermore, the end of its physical manifestation, while most likely, is unknown and usually not a doing of the actors who witnessed its birth. In perceptions of the future that is beyond our lifetimes, expanding into times that may not include us, these two processes are experienced as spaces in which the future reconstruction of the past, and therefore, history will be enabled. With time, the legacies of historical injustice fade away, so education and memorialisation are seen as fora for more permanent visibility of both recognition and accountability.

The temporal characteristics of the discussed memorialisation and education processes appear to be in contrast with state-led commemoration and public history education that are linear and exclusive of wider contexts; however, these dichotomies are not strict and can be destabilised in practice. Commemorating two or more conflicts together in particular can be detrimental to peace and justice goals as it can suggest that the society is trapped in a cycle of inter-ethnic hatred and violence. Such rhetoric has been employed by political elites in pursuit of nationalist agendas. To illustrate, the above reference to Ratko Mladić's statement upon entry into Srebrenica (referring to Bosniak population as 'Turks') is the kind of rhetoric that strategically portrayed continuity of harm and existence of 'ancient dangers' posed by the

93 Interview with a civil servant, 17 December 2019, Sarajevo.

94 Interview with an NGO representative and TJ expert, supra note 91.

95 For a discussion on the elements of temporality and law, see generally L.A. Khan, 'Temporality of Law', 40(1) McGeorge Law Rev. (2009) 55-106. 
other in order to accomplish a genocidal agenda. ${ }^{96}$ Similarly, formal education can utilise nationalistic narratives as 'indisputable historical truths' and seek to fixate group identities. ${ }^{97}$ Public history education in $\mathrm{BiH}$, segregated on ethnic bases, allows for the exercise of nationalist projects that remind pupils of their ethnic group's immense suffering through history, presented linearly. In stressing such victimhood but failing to portray the complexity of violence (and ethnicity) outside the sudden, violent ruptures, history education in particular cautions future generations of the possibility of renewed violence and victimisation by 'the other', for which, it is asserted, they should be ready. ${ }^{98}$ Outside $\mathrm{BiH}$, scholarship has raised concerns about the practices of placing the past in a proper timeframe, a process called 'historicization', whereby temporal distance and difference are regulated, resulting in 'legitimate' yet incomplete historical knowledge in history education. ${ }^{99}$

The linearity/circularity dichotomy in memorialisation and education in particular can and should be further nuanced by demonstrating their coexistence within singular processes. As Đureinović demonstrates in her study of memory politics in Serbia, state-led commemorative practices can manifest both continuities and variabilities. ${ }^{100}$ They can produce new victims, perpetrators, and ideologies supporting the institutions of memory while still insisting on preserving continuity of patterns of historical interpretation and actors. History education will likely accommodate these variabilities in memory politics, and this can in turn shape the resistance from non-state actors promoting alternative memorialisation and education processes.

Observing the limitations and blurs between and across distinct temporal regimes and different forms of memorialisation and education points to tensions due to which manifestations of recurrence, circularity, and continuity require contextualisation and rooting in their unique and shared circumstances. Criminal justice, with its time-boundness has the potential to soothe some of these tensions. In the following section, I discuss how the temporal

96 On the process of socially constructing Bosniaks as 'Turks' during the conflict, see E. Suljagić, 'Genocide by Plebiscite: The Bosnian Serb Assembly and Social Construction of "Turks" in Bosnia and Herzegovina', Journal of Genocide Research (2021) https://doi.org/ 10.1080/14623528.2021.1885570.

Bellino, Paulson and Anderson Worden, supra note 22. See also K.D. Bush and D. Saltarelli, The Two Faces of Education in Ethnic Conflict: Towards Peacebuilding Education for Children (UNICE F Innocenti Research Centre, Florence, 2000).

98 See Šimić, supra note 89.

99 M. Keynes, 'History Education for Transitional Justice? Challenges, Limitations and Possibilities for Settler Colonial Australia', 13(1) Int.J. Transit. Justice (2019) 113-133, p. 115.

100 J. Đureinović, The Politics of Memory of the Second World War in Contemporary Serbia. Collaboration, Resistance and Retribution (Routledge, Abingdon, 2020). 
regimes of time-boundness/timelessness and linearity/circularity can be reconciled in practice and what implications this has for the limitations of criminal justice, memorialisation and education.

\section{$5 \quad$ Bringing the Temporal Regimes Together}

With the closure of the ICTY and domestic war crimes proceedings in a rush to conclude their operations, more emphasis is placed on the afterlives of the strong criminal justice pillar in BiH. Trials' timebound legal functions of individual criminal accountability and specific deterrence seem to be in clash with the other, pedagogical and commemorative functions attached to criminal justice in transition that require long-term and widespread engagement with the public. ${ }^{101}$ Symbolically, trials are claimed to promote forward-looking goals of general deterrence and non-repetition of mass-scale violence and furthermore contribute to truth recovery by elaborating on the circumstance surrounding complex deviant acts such as genocide. ${ }^{102}$ As mentioned, the IRMCT assumes a few responsibilities the ICTY and the ICTR used to have, including 'preservation and management of archives.' ${ }^{103}$ Although the archives remain the UN's property and are located in The Hague, since 2005, they have been utilised by local actors. ${ }^{104}$ This development is not surprising for the work of international criminal tribunals. Already in 2004, the UN Secretary-General report on the Rule of Law and Transitional Justice saw tribunals as helping establish a historical record'. ${ }^{105}$ Later in the report, it was proposed that other TJ mechanisms are also needed to compensate for the limitations of criminal justice and complete, among others, a 'comprehensive historical record of what happened during the period of conflict and why'106

101 Simpson, supra note 68.

102 E.g., determining genocidal intent of the alleged perpetrator(s) necessitates scrutiny of contextual elements such as the general political doctrine, preparation, and repetitions of acts, attacks of cultural and religious property. See R. Petit, S. Ford and N. Jain, 'Exploring Critical Issues in Religious Genocide: Case Studies of Violence in Tibet, Iraq and Gujarat', 40(1) Case Western Reserve J. Int. Law (2007) 163-214.

103 The International Residual Mechanism for Criminal Tribunals, Functions, available online at https://www.irmct.org/en/about/functions (accessed 11 October 2019).

104 For instance, a local civil society organisation Humanitarian Law Centre has copied more than 115 OOO ICTY documents into its archive accessible by researchers, victims' associations, and any interested individuals. See Humanitarian Law Center, Archive of the ICTY Trials, available online at http://www.hlc-rdc.org/?page_id=17545\&lang=de (accessed 11 October 2019).

105 United Nations Secretary-General, "The Rule of Law and Transitional Justice in Conflict and Post-Conflict Societies' (S/2004/616*) p. 2. Ibid., p. 16. 
The idea that criminal justice along with other TJ processes can complete a 'comprehensive' historical record is reflected in numerous grassroots examples. In the efforts to combat the now widespread denial of the Srebrenica genocide and other war crimes that were committed in BiH, activists' main tools are court judgments: that of the ICTY, the ICJ, and the Court of BiH, all of which qualified the crimes in Srebrenica as 'genocide'. The time to rule on the crimes in Srebrenica is either passing or has already passed; yet the afterlives of these judgments can be long-lasting. There will be no going back and changing these judgments, so a person in the present can somewhat reliably count on their existence in the future.

Where would court records exist if not only in an archive in The Hague? For a reconciliation of temporal regimes, these and hundreds of other judgments need to establish roots in timeless and non-linear transitional justice processes. The proposition to extend the afterlives of criminal justice into memorialisation and education comes with a serious caveat. I do not wish to argue for criminal justice institutions to create historical accounts of past violent events. Firstly, they have a limited ability to do so due to strict legal requirements and disciplinary limitations. ${ }^{107}$ Secondly, making criminal law the sole authority on 'the truth' would be a manifestation of the force of law where the law, through its application, suppresses alternative interpretations and experiences of justice and violence. Resorting to criminal law and criminal law only could be seen as a forceful way of shaping and capturing historical meaning and the preferred collective memory. ${ }^{108}$ Thus to argue for a reconciliation of temporalities of criminal justice, on the one hand, and memorialisation and education, on the other, is not to argue for a blanket acceptance of the historical narrative created by criminal tribunals but for a harmonious inclusion of judicial recognition and accountability into less time-constrained processes.

Seeking to reconcile temporal regimes can also benefit education and memorialisation processes when such are controversial and have the potential to reinforce some of the harmful rhetoric of (ancient) hatred. A prominent way of aligning the temporal regimes is by using the documents produced by criminal justice institutions as factual foundations for memorialisation and education. The nevertheless political act of incorporation of the 'knowledge' produced by courts is welcome as a sort of consensus on the foundations of memorialisation and education on which manifestations of circularity can be built. While criminal justice institutions, primarily the ICTY, have been

108 O. Simić, 'Remembering, Visiting and Placing the Dead: Law, Authority and Genocide in Srebrenica', 13 Law Text Cult. (2009) 279-310. 
disliked, disapproved of and even challenged in the public, much of this being ethnically conditioned, ${ }^{109}$ the overarching belief among $\mathrm{TJ}$ actors in $\mathrm{BiH}$ is that the work of the ICTY is still 'the most objective thing that ever could have happened':110

An illustrative example is the two plaques, one in Bosnian and one in English, placed at the entrance to the newly restored City Hall in Sarajevo. The example was given by an interviewee from a local NGO who alluded that the language on the plaques was discriminatory. ${ }^{111}$ She further held that the ICTY Information Centre is located in the same building, which, in her view, should make the information about the appropriate language of accountability easily accessible. Memorial plaques should not say that the commemorated violations were committed by 'Serbs' or 'Chetniks' collectively, she asserted, 'but that army under that command,' to avoid labelling an entire ethnic group as criminal. ${ }^{112}$ Another contested qualification placed on a memorial was that of the word 'genocide' written on the above-mentioned monument in Višegrad. The Republika Srpska authorities opposed the wording because, they alleged, no criminal proceedings thus far have qualified the crimes committed in this town as 'genocide'. Eventually, the word 'genocide' was removed from the monument in 2014 and the rest, including bringing together victims of two wars, remains. ${ }^{113}$

In education, too, many TJ actors engage with court documents, most notably judgments issued by the ICTY and the Court of BiH. Such trends are well observed in the Memorial Centre Potočari, for instance, which relies on the ICTY judgments to tell the truth about the genocide in Srebrenica. The space hosts numerous posters with photographs of perpetrators and the sentences issued by the ICTY and video projections of testimonies. When I visited the Memorial Centre in November 2019, I watched a short film together with other visitors. The chronology of the events in Srebrenica in the film was reconstructed based on the ICTY findings. Furthermore, most, if not all civil society organisations interviewed also use court-established facts in their seminars, summer schools, and other informal educational interactions with the youth and the public to teach what happened.

Crucially, there are truths that criminal justice institutions have not yet told and probably never will due to their time-boundness. There, in the two timeless

109 See M. Milanović, 'The Impact of the ICTY on the former Yugoslavia: An Anticipatory Postmortem', 110(2) Am. J. Int. Law (2016) 233-259.

110 Interview with a BiH genocide scholar, 7 November 2019, Sarajevo.

111 The English language memorial plaque reads 'On this place, Serbian criminals in the night of 25th-26th August 1992 set on fire national and University's library of Bosnia and Herzegovina. ... Do not forget. Remember and warn!' The emphasis is mine.

113 Centar za nenasilnu akciju, supra note 23. 
processes, the criminal justice pillar is used as a legitimating foundation, a starting point. Court findings are not straightforwardly transmitted into either memorialisation or education, but TJ actors who work on these processes are often in a position to select which other stories are told and remembered and in what ways. Sometimes education is done in more experiential ways where sites of atrocities are visited and numerous competing stories from conflict are heard, and then judged together against any existing court judgments on the case or the area. ${ }^{114}$ In the case of a group of activists who mark the unmarked sites of atrocity across $\mathrm{BiH}$, their markings are usually, but not always buttressed by court rulings establishing that a war crime took place which gives legitimacy to their cause. Nevertheless, when a court ruling is missing, they rely on, among others, personal memories of survivors or war veterans to gather information about what happened at a particular site. ${ }^{115}$ Investigative journalists follow that logic, too. In the Transitional Justice program of the Balkan Investigative Reporting Network, for example, the editorial policy strictly necessitates stories to be supported by court findings. ${ }^{116}$ Nevertheless, occasionally, the journalists find it necessary to report on a story that has not been adjudicated on. In that case, the reportage would not focus on individual criminal responsibility, but rather invite interpretations from the audience by presenting evidence.

The idea is that out of these negotiations in memorialisation and education processes, which are and will keep being informed by criminal justice doings in the future, emerges a historical, and inevitably, political consensus. This future consensus would, after all, reconstruct the past as we know it today. The consensus is first and foremost made about qualifications of criminal acts and criminal groups and individuals, which is where criminal justice is widely used as a factual foundation. In acknowledging lived experiences of injustice that are not captured by criminal justice, these processes refer to criminal justice as a legitimating foundation to point to how widespread, diverse, and pervasive violence was but expand beyond the past as captured by criminal justice alone. Through these negotiations, the processes of memorialisation and education also gain legitimacy to disturb some of the dominant state or entity-led commemorative narratives that may run in a different temporal regime and/ or distinct historical interpretation. Political elites' resistance to collective memory and the co-option of individual memories inevitably slows down these processes. This aspect is not to be forgotten. However, temporal reconciliations, as illustrated above, have been taking place and taking roots and

\footnotetext{
114 Interview with NGO representative, supra note 92; Interview with NGO representative and TJ expert, supra note 91.

115 Interview with an NGO representative, 4 February 2020, Sarajevo.

116 Interview with a program director, 20 February 2020, Belgrade.
} 
gaining interest and support of the more technocratic TJ structures, prolonging the afterlives of criminal justice. Reconciling dichotomies of temporality in criminal and non-institutional $\mathrm{TJ}$ thereby begins to look like a more holistic approach to transitional justice, one that observes and acknowledges both temporal regimes of linearity/circularity and time-boundness/timelessness. When the timeless processes of memorialisation and education tie the principles of recognition and accountability that stem from criminal justice to them, they can transcend the linear project of 'dealing with the past' by pointing to continuities, circularities, and contextualities, expand it across generations and in doing so, extend as well as complement the efforts made by the timebound criminal justice.

Conclusion

This article has investigated the temporal regimes associated with criminal justice, memorialisation, and education, and discussed the possibilities and implications of reconciling these temporal dichotomies in practice. It has been argued that contemporary transitions cannot only be understood as breaks in linear time in which the past is 'dealt with' so that a better future can begin. Instead, numerous empirical examples showed that the past, and all the violence and grievances that come with it, as well as the future are reconstructed in the present. This article, therefore, calls for earlier and more encompassing outreach in future international criminal justice contexts whereby non-conventional TJ processes, and memorialisation and education in particular, are prioritised as spaces that both accommodate the afterlives of criminal justice and compensate for some of its inherent shortcomings stemming out of time-boundness and linear legal procedure. Simultaneously, processes of memorialisation and education can benefit from reconciliation with criminal justice, with all its limitations, to avoid potentially perpetuating what they seek to challenge and add legitimacy to the challenges they pose to certain state-led commemorative and educational practices rooted in nationalist agendas. In the era where ensuring non-repetition of violence is the overarching telos of transitional justice, distinct temporalities of violence and justice ought to be studied and negotiated in an effort to avert such recurrence. To that end, future research might wish to investigate the temporal dichotomies in or together with other $\mathrm{TJ}$ mechanisms and processes such as reparations and institutional reform.

In transitional contexts, it is evident that criminal justice, where wanted, is urgent due to its time-boundness. The lesson that should be learned from $\mathrm{BiH}$ 
is that this urgency made criminal justice, in addition to institutional reform, the sole acknowledged TJ processes for a long time. While the passage of time signals the end of criminal justice, it does not mean that all justice matters are over, far from it. There are numerous recent examples of applications of TJ-related measures for crimes committed dozens of years ago, including, for instance, WWII-era property restitution, ${ }^{117}$ and apologies offered for colonial violence, ${ }^{118}$ some of which have been better received than others by the affected communities. These interpretations of justice are distinct from retributive justice that courts can otherwise render. The passage of time also allows some distance from the conflict to be taken, during which the priorities for the future are constantly rethought. In addition, personal processes of transitional justice are long-lasting, they require transformations of the culture of public speaking and public consciousness. These personal and long-lasting processes are processes of a transitional justice character, yet they often escape the official $\mathrm{TJ}$ labelling as they are not easily turned into projects; they continue after the official $\mathrm{TJ}$ project $\mathrm{t}^{119}$ is finished and after criminal tribunals close their doors. In transitional justice contexts to come, the imperative is to understand that progression, the brighter future, does not flow linearly nor quickly from addressing the past through criminal justice and institutional reform. It is to observe the need for sustainability and longue durée of the processes of transitional justice, long after the trial ends, and to observe the complex and multiple temporalities attached to these processes. It is when the projects and processes of transitional justice interact that it becomes apparent that 'dealing' with the past never stops and that harmony between temporal regimes could arise.

\section{Acknowledgements}

I would like to thank Annika Jones, Catherine Turner, Padraig McAuliffe, Noha Aboueldahab, members of the Conflict+ research group at Durham Global Security Institute, and the anonymous reviewers for their helpful comments on earlier versions of this article. I am also grateful to the Open Society Foundations for supporting this research with their generous Civil Society Scholar Award.

117 Maja Davidović, 'Rectification of Racial Discrimination during WWII: the Case of Restitution Laws in Serbia', 4(1) Contemporary Southeastern Europe (2017) 105-118.

118 K.E. McGregor, 'Time, memory and historical justice: An introduction', 21(1) Time Soc. (2012) $5^{-20 .}$

119 See R. Nagy, 'Transitional Justice as Global Project: Critical Reflections', 29(2) Third World Q. (2008) $275^{-289}$. 